International Journal of Linguistics, Literature and Culture
Available online at https://sloap.org/journals/index.php/ijllc/
Vol. 6, No. 5, September 2020, pages: 41-48
ISSN: 2455-8028
https://doi.org/10.21744/ijllc.v6n5.990

\title{
An Exploration of English Teachers' Beliefs and Practices of Speaking Assessment: Bring English Teachers into Focus
}

\section{Article history:}

Submitted: 27 July 2020

Revised: 18 August 2020

Accepted: 9 September 2020

\section{Keywords:}

assessment;

beliefs;

practices;

speaking;

teachers;

\begin{abstract}
The present study aimed at exploring and describing English teachers' beliefs and their practices of speaking assessment through a semi-structured interview. This study employed a qualitative method. There were two sets of research questions: (1) What were English teachers' beliefs about their roles in assessing students' speaking? (2) How did English teachers assess students' speaking? There were nine teachers from three different levels of education participated in this study. The findings indicated that the beliefs of English teachers and their practices in assessing speaking were not always aligned with one another due to some factors. The pedagogical implications of the study included a need for (1) guidance to teachers in how to conduct a good speaking assessment, (2) guidance to teachers in how to develop their speaking assessment rubric that can be modified to meet the needs of the school context and later build the accountability system at the school.
\end{abstract}

International journal of linguistics, literature and culture (C) 2020.

This is an open access article under the CC BY-NC-ND license

(https://creativecommons.org/licenses/by-nc-nd/4.0/).

Corresponding author:

Didin Nuruddin Hidayat,

Faculty of Educational Sciences Universitas Islam Negeri Syarif Hidayatullah Jakarta

Jl. Ir. H. Juanda No. 95 Ciputat 15412, Tangerang Selatan, Indonesia

Email address: didin.nuruddin@uinjkt.ac.id

\footnotetext{
${ }^{a}$ Faculty of Educational Sciences Universitas Islam Negeri Syarif Hidayatullah Jakarta, Indonesia

${ }^{\mathrm{b}}$ Faculty of Educational Sciences Universitas Islam Negeri Syarif Hidayatullah Jakarta, Indonesia

${ }^{\mathrm{c}}$ Faculty of Educational Sciences Universitas Islam Negeri Syarif Hidayatullah Jakarta, Indonesia
} 


\section{Introduction}

In the education system, one important aspect that was closely related to the curriculum for determining the success or failure of the teaching and learning process was evaluation (Nunan, 2015). An evaluation was defined as a systematic application of scientific methods to assess the design, implementation, advancement, or results of a program (Desheng, 2013). In this context, William (2013), argued that no matter how carefully the instruction was designed and implemented, what students learned could not be predicted with any certainty. He emphasized that it was only through assessment; we could discover whether the instructional activities in which students were engaged resulted in the intended learning.

Teachers in the educational system were actively and continuously involved in assessment for their students. However, investigations of teachers' assessment practices revealed that teachers were not well prepared to meet the demand for classroom assessment due to inadequate training (Zhang \& Burry-stock, 2003). It was found that problems were particularly prominent in performance assessment, interpretation of standardized test results, and grading procedures. When using performance measures, many teachers did not define levels of performance or plan scoring procedures before instruction. Many of them also did not record scoring results during assessment specifically, or they only give overall and general scores. In terms of interpretation of standardized testing, teachers were reported having engaged in teaching test items, increasing test time, giving hints, and changing students' answers. It was also found that teachers had trouble interpreting standardized test scores and communicating test results. Also, many teachers incorporated non-achievement factors such as effort, attitude, and motivation into grades, and they often did not apply weights in grading to reflect the differential importance of various assessment components.

Essentially, the purpose of the assessment was to allow students to show what they had learned (Maba et al., 2018). The assessment gave and helped teachers, administrators, and those involved some information about how students should be placed in the course of study, how they were performing in the class, and how an actual language program was performing. Moreover, the assessment gave the learners insight into how they were learning and progressing in language programs and should provide beneficial feedback to everyone involved in a language program (Jabbarifar, 2009). Therefore, at various points in the teaching and learning process, particularly at the end, assessment in the form of a test was administered by teachers to their students as a part of the evaluation.

The test was continuously encountered in education. In educational settings, teachers tested their students because they wanted to find out whether their students mastered the content and material of lessons that had been taught in the teaching and learning process. Particularly in schools, testing was usually administered on the purpose of assessment, to assign students grades, or rank the students in terms of their abilities (Roediger et al., 2011). When test results had been obtained, then teachers could find out the weakness and strengths of their students and take appropriate steps for further teaching. Thus, the test was viewed as a tool for measuring students' mastery of skills and knowledge. In a broader aspect, tests were used to hold schools accountable for their students' progress and monitor the progress of students as individuals (Marsh, 2007). Hence, a test was administered to students for assessment to get information about students' learning as a part of the evaluation in the teaching and learning process (Rubin \& Smith, 1990; Chien et al., 2020; Yiu, 1992).

Concerning testing as a part of the evaluation, the test should be focused on the teaching objectives. In many educational systems, what was taught determined what was to be assessed (Nunan, 2015). Further, in developing test items and scoring criteria, Pitoniak et al. (2009), argued that they should be matched with the task to the purpose. In Pitoniak's view, the test item should be linked directly to the test specifications and content standards, also to the content and the skill that the item was supposed to measure. Therefore, there were specific qualities expected of a good language test, which included validity, reliability, objectivity, and economy (Foyewa, 2015) as the ways to give some quality assurance of the test.

Speaking assessment was an important element in language tests. Generally, evaluating oral communication was regarded as the most difficult to score, administer, and prepare. Those difficulties emerged due to some components in assessing speaking, which was needed to produce a reliable score. Some of the components were pronunciation, grammar, vocabulary, fluency, listening comprehension, and appropriateness. Nevertheless, assessing speaking should be based on the given materials of instruction referring to the goals and objectives of instruction in the syllabus.

Speaking assessment in the classroom should be conducted in systematic ways such as creating some assessment steps, which included identifying objectives of instruction, assessment planning, and developing rubrics or score procedures (Suwandi, 2009). Further, Suwandi (2009), argued that rubrics with a more detailed description of 
students' levels of performance would help scoring procedures to minimize subjectivity in speaking tests. He also emphasized that selecting proper activities was also helpful for the teachers to reach the goal and objective of the assessment. Ayhan \& Türky1lmaz (2015), also stated that rubrics played a key role in the evaluation of the proficiency of students by providing validity and reliability. In terms of the accountability purpose, for example, rubrics had been argued to serve as guidance for dealing with subjectivity in speaking tests. Rubrics were often regarded as an integral part of a strong, objective, and effective assessment tool since it was useful for formative or for learning, and summative assessment or assessment of learning purposes (Ulker, 2017). Similarly, Phuong \& Phan (2017), suggested that rubrics were considered as a useful instructional and assessment tool in speaking assessment. For these reasons, rubrics had been used for speaking assessments in many existing studies.

Several existing studies had addressed rubrics for speaking assessment (e.g., Jannah, 2018; Leong \& Ahmadi, 2017). Moreover, experimental studies on assessing speaking employed rubrics to determine what criteria to choose in evaluating oral communication (e.g., Loganathan, 2017; Nur Iman, 2017). To contribute to the language testing and assessment with a concern to rubric use, Saeed et al. (2019), had developed and tested a new speaking proficiency test and proposed a new speaking assessment rubric with a new set of descriptions for each band. He argued that the assessment of learning had been replaced by an assessment for learning in today's teaching and learning pedagogy. Thus, this shift allowed developing rubric with more specific descriptors for serving the next stage of learning.

However, studies indicated that teachers' work was highly influenced by their beliefs. Teachers' beliefs had effects on teachers' teaching behavior, decision-making, and also shaping the teachers' planning and curricular decisions, which were, in return effecting to determine what should be taught and what kind of instruction should follow (Xu, 2012; Lyon, 2011). Accordingly, teachers' beliefs had not been notoriously defined, but most definitions of belief proposed that belief disposed of or guided people's thinking and action. Particularly in speaking assessment, the beliefs of English teachers had a significant role in how to conduct a good speaking assessment, which was closely related to their values, their views of the world, and their understanding of their place within it.

For these reasons, the present study aimed at exploring and describing English teachers' beliefs and their practices about speaking assessment and its rubric through a semi-structured interview. This study was limited to the two sets of research questions: (1) What were English teachers' beliefs about their roles in assessing students' speaking? (2) How did English teachers assess students' speaking?

\section{Materials and Methods}

This present study aimed at exploring and describing English teachers' beliefs and their practices of speaking assessment. In this study, the qualitative method was employed through a semi-structured interview. Nine English teachers (two males and seven females) teaching in three different levels of education participated in this study; there were three primary school teachers, three junior high school teachers, and three senior high school teachers in and around South Tangerang, Banten Province, Indonesia. Their age was between 25-35 years old. Participants' educational backgrounds were generally different in terms of the university they graduated, but all of them graduated from university with English as their major. They also have different teaching experiences, including the length of teaching practice. One of them had less than three years of teaching experience. Five of them had between 4-6 years of teaching experience, while two others had been teaching between 7-9 years. The participants were chosen based on convenience and accessibility. A semi-structured interview was employed for two sets of research questions:

(1) What were the teacher's beliefs about their roles in assessing students' speaking?

(2) How did teachers assess students' speaking?

In this study, the findings were divided into two categories: a) teacher's beliefs and practices about their roles in assessing students' speaking, b) teacher's beliefs, and practices of speaking assessment.

\section{Results and Discussions}

For the most part, English teachers looked at speaking assessments from different perspectives, associating it with giving grades and feedback. However, it could be said that there was a generalized idea of speaking assessment. The answers provided by the participants in this present research only gave an account of speaking assessment as a procedure to which grades were assigned to students.

Nurhalimah, N., Husna HR, N., \& Hidayat, D. N. (2020). An exploration of English teachers' beliefs and practices of speaking assessment: bring English teachers into focus. International Journal of Linguistics,

Literature and Culture, 6(5), 41-48. https://doi.org/10.21744/ijllc.v6n5.990 


\section{Teachers' beliefs and practices about their roles in assessing students' speaking}

When asked about the English teachers' roles in assessing students' speaking, the teachers seemed to agree that speaking assessment was not only about giving scores; teachers played a key role as facilitator, assessor, evaluator, and sometimes a prompter (Tsiplakides \& Keramida, 2009; Mohd Saad et al., 2013). Teachers should facilitate their students on how they could improve themselves, for example, by boosting their confidence (Webb, 2009; Tsiplakides \& Keramida, 2009). One teacher viewed that teachers had to give feedback to students, and it should be a face to face feedback for evaluating their speaking performance, so the students had an opportunity to know their strength and weakness. Helping the students to understand the goal of their learning and show them the way to achieve it would also become teachers' record of their students' progression (Brookhart, 2011). By giving feedback, the teacher also said, allowed teachers to know where their students were at. One teacher viewed that if students failed in a certain speaking assessment, for example, teachers needed to change their approach in teaching as the mistakes might occur because of the teacher themselves in the process of teaching and learning.

In the practices, some participants put themselves as prompter and facilitator when students encountered problems in the speaking activities by giving hints for ideas, motivation, and encouragement. In contrast to the general idea that teachers played an important role as a prompter and facilitator, one teacher put himself only as an evaluator who evaluated their students by providing an evaluation format for their students in the practices of speaking assessment. When asked about the reason why he put himself only as an evaluator, the teacher seemed to believe that it was a requirement to determine whether a student passed or failed in the speaking test. Indeed he had a different perspective about his role during the evaluation. At the same time, it was understandable due to some factors, and it should be well noticed that various beliefs occurred in the field (Remesal, 2011). It was clearer than the reason for doing speaking assessment reflected a summative purpose in his speaking assessment practice. Thus, this information revealed an important issue: teachers gave more importance to the administrative side of assessment with little consideration of assessment for learning. It was, of course, debatable to promptly said that he did not have the competence as a teacher. However, the ability to perform his role as more than an evaluator when conducting the assessment should have emerged (Yin, 2010).

As a teacher, it was indeed important to possess good management skills to help students' improvement (Yin, 2010); however, neglecting the real objective of the assessment would not be considered as an achievement in the process. The design of the test should have a dynamic relationship that the former should be the mirror of the latter (Giraldo Aristizábal, 2018). Understanding how the assessment should be implemented as the effort to find out the success of the teaching-learning process was one of the teacher's competence cores (Huang \& He, 2016). Therefore, arranging the administrative work to be compatible with the objectives of the teaching speaking itself was one of the fundamental skills of teachers.

Since speaking held different characteristics from other skills, the way it was being tested might also be different. In the speaking tests, usually, there would be some judgment on the students' ability to pronounce properly with little to no traces of the mother tongue (Kim, 2010); therefore, a performance as one way to assess speaking ability should be conducted. Performance in speaking could be assessed both directly or indirectly. The former, of course, would require a lot of test time and well-experienced test givers of teachers (Ginther, 2013). Ginther (2013), also stated that even though indirect methods such as using video or voice recorder was quite helpful and reliable to score the students' speaking ability, the direct one such as the actual performance would be the better as the way to investigate students' speaking skills. To be able to assess speaking performance ideally, the teachers would need to be well trained, both in language mastery itself and in the assessment field (Fulcher, 2010; Kim, 2010; Ginther, 2013; Stabler-Havener, 2018).

\section{Teachers' beliefs and practices of speaking assessment}

One teacher viewed that speaking assessment served as a basic assessment that told a lot about students' abilities in the English language. It was believed that students with great speaking performance had great ability in the English language (Ansarey, 2012; Nazara, 2011; Uzer, 2018). Meanwhile, others viewed that speaking assessment was only a part of assessments in English subjects because students' English ability could be judged in many ways (Cumming, 2013; Aydoğan \& Akbarov, 2014). When asked about teachers' beliefs and practices of speaking assessment, findings suggested that teachers assessed different aspects of what was assessed in their speaking assessment.

Most English teachers mentioned that there were many aspects of speaking to be assessed. Ideally, speaking assessment should put weigh on important aspects such as pronunciation, grammar, vocabulary, fluency, 
comprehension, content, time-management (Khamkhien, 2010). However, the majority of the participants (70\%) paid close attention when assessing speaking students more on grammar and vocabulary. They looked at the correct use of grammar and rich vocabulary and decided about their students' ability to speak English based on the use of those two.

Furthermore, the majority of the participants were at the same thought that rubrics played a crucial role in speaking assessment since it provided guidelines for scoring criteria. They believed that using the rubric will provide a more reliable system in scoring (Schreiber et al., 2012). Rubrics were employed as they helped a lot to guide teachers on what to assess in their speaking performance (Latifa et al., 2015). However, putting weigh on certain aspects for the scoring criteria was based on the students' needs and the teaching objectives (Reddy \& Andrade, 2010).

In the practices of speaking assessment, most English teachers preferred different speaking rubric. Some teachers preferred adopting, some preferred adapting, and others preferred creating a new speaking rubric by taking into account the goal of the teaching, the scale, and the scoring criteria as well. The speaking rubrics typically included pronunciation, grammar, vocabulary, fluency, comprehension, content, time-management. For the scoring criteria, teachers were different on what aspects should be given more emphasis. However, only a few teachers reported on giving feedback by pointing out what students missed in the scoring criteria in rubrics. Preparing proper rubric should have relied on the objective of the teaching-learning process itself (Davis, 2015). Therefore, clear objectives in every stage of the teaching-learning process should be stated properly. Besides, the objectives will help to guide the teachers in preparing their class activities.

About how the speaking assessment was done, oral presentation, dialogs, drama, responsive speaking, interactive speaking, v-log, or self-directed video were ways how English teachers conducted speaking assessment. Teachers reported using different tasks to assess speaking performance depending on the objectives of the teaching English as required in the basic competence in the syllabus and the students' needs (Davis, 2015). Group work could be used to make the scoring process went faster and encouraged students to practice. However, grouping without proper supervision and guidance did not guarantee that the students learn to speak (Webb, 2009). Therefore, teachers' awareness of guiding and supervising was crucial to make the activities more meaningful for the learning process.

Furthermore, some teachers reported on doing speaking assessments only in the formal assessment. Others said they did a speaking assessment when there was an opportunity to do so in an informal way, for example, when students were having a lunch break. The teachers heard their students were having a conversation in English. It was still in agreement that actual performance was the best way to find out students' speaking ability (Ginther, 2013). Nonetheless, it was not easy to make it as one of the reliable processes because it could not reach all students and took more time and specific chances.

However, when it came to the scoring procedures, findings reflected a concern on personality factors. In the primary level, the scores in the speaking assessment were based on the accumulation of scores given by every English teacher because English subject was taught as separate skills by different teachers. Furthermore, the speaking rubric used to help them to minimize the subjectivity in administering a speaking assessment was only in the form of a branch score without a detailed description of levels of performance of students. Concerning the interpretation of scoring results, students' performance was compared with the standard score of the course content.

In other cases, some teachers seemed to agree that personal factors from the students' side affected the scoring procedures. For instance, how confident students feel, their nervousness, and anxiety are personal factors that some teachers considered in the scoring procedures in speaking assessment practices. Indeed, the probability of being nervous, anxiety, motivation, and other personal factors during the speaking test, especially the direct ones, might influence the students' performance (Khamkhien, 2010; Mak, 2011; Khoiriyah, 2016; Putri et al., 2020).

\section{Conclusion}

The findings of the study showed that English teachers had some weaknesses regarding speaking assessment. Teachers were well aware of what and how to assess. Teachers were aware that speaking assessment should be focused on the objectives of teaching. They were also aware of the benefits of using rubrics in the assessment; rubrics could facilitate speaking assessment to provide better results in dealing with objectivity.

However, very few teachers gave reasons for speaking assessment as a procedure to which grades were assigned to students. In this study, only a few teachers reported on giving feedback by pointing out what students missed in

Nurhalimah, N., Husna HR, N., \& Hidayat, D. N. (2020). An exploration of English teachers' beliefs and practices of speaking assessment: bring English teachers into focus. International Journal of Linguistics,

Literature and Culture, 6(5), 41-48. https://doi.org/10.21744/ijllc.v6n5.990 
the scoring criteria in rubrics. Thus, it appeared that speaking assessment only implied assigning grades to students with little consideration on assessment for learning.

Nevertheless, it was widely agreed that the beliefs and practices of speaking assessment were not always aligned among teachers. In this present study, the diverse beliefs and practices of speaking assessment occurred among English teachers seemed due to some factors, such as participants' educational backgrounds, teaching experiences, and school context that affected their views of English language teaching and learning as well as its assessment process.

As a final thought, it was also important to be noted that English language teachers needed to consider developing their speaking rubrics that met the needs of the school context. The implications of the study were the awareness of English teachers on the role of speaking rubrics to finally begin designing their speaking rubrics that could be modified to meet the needs of the school context and later built the accountability system at the school.

\section{Conflict of interest statement}

The authors declared that they have no competing interests.

\section{Statement of authorship}

The authors have a responsibility for the conception and design of the study. The authors have approved the final article.

\section{Acknowledgments}

We are grateful to two anonymous reviewers for their valuable comments on the earlier version of this paper. 


\section{References}

Ansarey, D. (2012). Communicative Language Teaching in EFL Contexts: Teachers Attitude and Perception in Bangladesh. ASA University Review, 6(1).

Aydoğan, H., \& Akbarov, A. A. (2014). The four basic language skills, whole language \& intergrated skill approach in mainstream university classrooms in Turkey. Mediterranean Journal of Social Sciences, 5(9), 672-672.

Ayhan, Ü., \& Türkyılmaz, M. U. (2015). Key of language assessment: Rubrics and rubric design. International Journal of Language and Linguistics, 2(2), 82-92.

Brookhart, S. M. (2011). Educational assessment knowledge and skills for teachers. Educational Measurement: issues and practice, 30(1), 3-12. https://doi.org/10.1111/j.1745-3992.2010.00195.x

Chien, S. Y., Hwang, G. J., \& Jong, M. S. Y. (2020). Effects of peer assessment within the context of spherical video-based virtual reality on EFL students' English-Speaking performance and learning perceptions. Computers \& Education, 146, 103751. https://doi.org/10.1016/j.compedu.2019.103751

Cumming, A. (2013). Assessing integrated skills. The companion to language assessment, 1, 216-229. https://doi.org/10.1002/9781118411360.wbcla131

Davis, L. (2015). Designing and using rubrics.". Dalam J. D. Brown, \& C. Coombe, The Cambridge Guide to Research in Language Teaching and Learning (hal. 238-246). Cambridge: Cambridge University Press.

Desheng, C., \& Varghese, A. (2013). Testing and evaluation of language skills. IOSR Journal of Research \& Method in Education (IOSR-JRME) e-ISSN, 2320-7388.

Foyewa, R. A. (2015). Testing and Evaluation in English Language Testing. International Journal of English Teaching, 3(6), 32-40.

Fulcher, G. (2010). Practical language testing. London: Hodder Education. http://dx.doi.org/10.1017/S027226311100043X

Ginther, A. (2013). Assessment of speaking. The Encyclopedia of Applied Linguistics.

Giraldo Aristizábal, F. (2018). A Diagnostic study on teachers' beliefs and practices in foreign language assessment. Íkala, revista de lenguaje y cultura, 23(1), 25-44. http://dx.doi.org/10.17533/udea.ikala.v23n01a04

Huang, J., \& He, Z. (2016). Exploring assessment literacy. Higher Education of Social Science, 11(2), 18-27.

Iman, J. N. (2017). A Quasi-Experimental Study on Using Short Stories: Statistical and Inferential Analyses on the Non-English Major University Students' Speaking and Writing Achievements. Online Submission, 5(1), 421-433.

Jabbarifar, T. (2009). The importance of classroom assessment and evaluation in educational system. In Proceedings of the 2nd International Conference of Teaching and Learning (pp. 1-9).

Jannah, W., \& Hartono, R. (2018). Students' Speaking Assessment Used by English Teachers Based on the 2013 Curriculum. English Education Journal, 8(3), 359-369.

Khamkhien, A. (2010). Teaching English Speaking and English Speaking Tests in the Thai Context: A Reflection from Thai Perspective. English Language Teaching, 3(1), 184-190.

Khoiriyah, S. L. (2016). The correlation among attitude, motivation and speaking achievement of college students across personality factors. OKARA: Jurnal Bahasa dan Sastra, 10(1), 78-92. http://dx.doi.org/10.19105/ojbs.v10i1.813

Kim, H. J. (2010). Investigating the construct validity of a speaking performance test. SPAAN FELLOW, 1.

Latifa, A., Rahman, A., Hamra, A., Jabu, B., \& Nur, R. A. (2015). Developing a Practical Rating Rubric of Speaking Test for University Students of English in Parepare, Indonesia. English Language Teaching, 8(6), 166-177.

Leong, L. M., \& Ahmadi, S. M. (2017). An analysis of factors influencing learners'english speaking skill.

Loganathan, S. (2017). Enhancing Speaking Skills of the Technical L2 Learners through Mobile-assisted Tool. International Interdisciplinary Research Journal, 5(12), 1-7.

Lyon, E. G. (2011). Beliefs, practices, and reflection: Exploring a science teacher's classroom assessment through the assessment triangle model. Journal of Science Teacher Education,22(5), 417. https://doi.org/10.1007/s10972-011-9241-4

Maba, W., Perdata, I. B. K., Astawa, I. N., \& Mantra, I. B. N. (2018). Conducting assessment instrument models for teacher competence, teacher welfare as an effort to enhance education quality. International research journal of management, IT and social sciences, 5(3), 46-52.

Mak, B. (2011). An exploration of speaking-in-class anxiety with Chinese ESL learners. System, 39(2), 202-214. https://doi.org/10.1016/j.system.2011.04.002

Marsh, E. J., Roediger, H. L., Bjork, R. A., \& Bjork, E. L. (2007). The memorial consequences of multiple-choice testing. Psychonomic Bulletin \& Review, 14(2), 194-199. https://doi.org/10.3758/BF03194051

Nurhalimah, N., Husna HR, N., \& Hidayat, D. N. (2020). An exploration of English teachers' beliefs and practices of speaking assessment: bring English teachers into focus. International Journal of Linguistics, Literature and Culture, 6(5), 41-48. https://doi.org/10.21744/ijllc.v6n5.990 
Mohd Saad, M. R., Sardareh, S. A., \& Ambarwati, E. K. (2013). Iranian secondary school EFL teachers' assessment beliefs and roles. Life Science Journal, 10(3), 1638-1647.

Nazara, S. (2011). Students' perception on EFL speaking skill development. JET (Journal of English Teaching), 1(1), 28-43. https://doi.org/10.33541/jet.v1i1.50

Nunan, D. (2015). Teaching English to speakers of other languages: An introduction. Routledge.

Phương, H. Y., \& Phan, T. X. (2017). Using Analytic Rubric for Speaking Self-Assessment: EFL Students' Perceptions and Challenges.

Pitoniak, M. J., Young, J. W., Martiniello, M., King, T. C., Buteux, A., \& Ginsburgh, M. (2009). Guidelines for the assessment of English language learners. Princeton, NJ: Educational Testing Service.

Putri, S. A., Amri, S., \& Ahmad, A. (2020). THE STUDENTS'DIFFICULTIES FACTORS IN SPEAKING. JShelves of Indragiri (JSI), 1(2), 115-129.

Reddy, Y. M., \& Andrade, H. (2010). A review of rubric use in higher education. Assessment \& evaluation in higher education, 35(4), 435-448. https://doi.org/10.1080/02602930902862859

Remesal, A. (2011). Primary and secondary teachers' conceptions of assessment: A qualitative study. Teaching and teacher education, 27(2), 472-482. https://doi.org/10.1016/j.tate.2010.09.017

Roediger III, H. L., Putnam, A. L., \& Smith, M. A. (2011). Ten benefits of testing and their applications to educational practice. In Psychology of learning and motivation (Vol. 55, pp. 1-36). Academic Press. https://doi.org/10.1016/B978-0-12-387691-1.00001-6

Rubin, D. L., \& Smith, K. A. (1990). Effects of accent, ethnicity, and lecture topic on undergraduates' perceptions of nonnative English-speaking teaching assistants. International journal of intercultural relations, 14(3), 337-353. https://doi.org/10.1016/0147-1767(90)90019-S

Saeed, K. M., Ismail, S. A. M. M., \& Eng, L. S. (2019). Malaysian Speaking Proficiency Assessment Effectiveness for Undergraduates Suffering from Minimal Descriptors. International Journal of Instruction, 12(1), $1059-1076$.

Schreiber, L. M., Paul, G. D., \& Shibley, L. R. (2012). The development and test of the public speaking competence rubric. Communication Education, 61(3), 205-233. https://doi.org/10.1080/03634523.2012.670709

Stabler-Havener, M. L. (2018). Defining, conceptualizing, problematizing, and assessing language teacher assessment literacy. Studies in Applied Linguistics and TESOL, 18(1). https://doi.org/10.7916/salt.v18i1.1195

Suwandi. (2009). Designing Speaking Test. Eksplanasi, 4(8), 183-191.

Tsiplakides, I., \& Keramida, A. (2009). Helping Students Overcome Foreign Language Speaking Anxiety in the English Classroom: Theoretical Issues and Practical Recommendations. International Education Studies, 2(4), 39-44.

Uzer, Y. V. (2018). The Correlation between Vocabulary Mastery and English Speaking Ability of the Tenth Grade Students of Senior High School 12 Palembang. ANGLO-SAXON: Jurnal Ilmiah Program Studi Pendidikan Bahasa Inggris, 8(2). http://dx.doi.org/10.33373/anglo.v8i2.1225

Webb, N. M. (2009). The teacher's role in promoting collaborative dialogue in the classroom. British Journal of Educational Psychology, 79(1), 1-28.

Wiliam, D. (2013). Assessment: The bridge between teaching and learning. Voices from the Middle, $21(2), 15$.

$\mathrm{Xu}, \mathrm{L}$. (2012). The Role of Teachers' Beliefs in the Language Teaching-learning Process. Theory \& Practice in Language Studies, 2(7).

Yin, M. (2010). Understanding classroom language assessment through teacher thinking research. Language Assessment Quarterly, 7(2), 175-194. https://doi.org/10.1080/15434300903447736

Yiu, E. M. (1992). Linguistic assessment of Chinese-speaking aphasics: Development of a Cantonese aphasia battery. Journal of Neurolinguistics, 7(4), 379-424. https://doi.org/10.1016/0911-6044(92)90025-R

Zhang, Z., \& Burry-Stock, J. A. (2003). Classroom assessment practices and teachers' self-perceived assessment skills. Applied Measurement in Education, 16(4), 323-342. https://doi.org/10.1207/S15324818AME1604_4 